Clavius's 'method of prosthaphæresis' is almost an anticipation of calculation by logarithms ( $p$. 459). Continued fractions are first found in Bombelli's ' $L$ ' Algebra parte maggiore dell' aritmetica divisa in tre libri" $(1572$, p. 80); Cataldi (1613) gives what is practically the usual symbolism.

G. H. HARDY.

\section{Welsh Folk-lore.}

Welsh Folk-lore and Folk-Custom. By Prof. T. Gwynn Jones. Pp.xx +255. (London: Methuen and Co., Ltd., 1930.) 7s. 6d. net.

$\mathrm{P}$ ROF. GWYNN JONES'S little book on Welsh folk-lore is a welcome companion and supplement to Miss Hull's "Folk-lore of the British Isles" in the same series. The author is able to deal in greater detail with topics on which Miss Hull could do little more than touch in covering the larger area. Here we have presented within a relatively small compass a much fuller statement of the chief features of the lore and custom of the Welsh people.

The composite character of English folk-lore and custom has often been pointed out. The same character is to be attributed to Welsh folk-lore in even a greater degree, where indeed it would seem probable that more of the earlier phases of primitive custom and belief have survived. This, perhaps, might have been expected from the cultural history of the principality. Settlers seem to have absorbed the tradition and culture of the earlier population to a greater degree than in England. It will be remembered that Giraldus Cambrensis noted this as characterising Norman invaders in Ireland, who became "Hiberniores ipsis Hibernicis".

The survival of very early tradition is exemplified in the stories of the Mabinogion, in which elements of a most primitive character are to be found side by side with features characteristic of the chivalrous civilisation of Norman times. Fairies and giants both figure prominently. As the late Sir John Rhys pointed out, the former are often of a preiron or even pre-metal age, as for example in the stories of the fairy-wife who vanishes on being struck accidentally by iron.

Prof. Gwynn Jones has devoted himself in the main to a record of fact ; theories as to origins and parallels are mostly avoided. This is no doubt wise in view of the importance of securing a record of facts as extended as possible before they vanish entirely. But in a few cases a consideration of parallels found elsewhere would be of assistance to the reader who is not a specialist. As an example, the Mari Lwyd, the custom that at certain times a person known as Mari should carry round a horse's skull, should be compared with the similar traditional practice in the Isle of Man and at Ramsgate. It is suggested here that the custom may be connected with marriage ; but more probably it is a general fertility rite which has been adapted to special occasions and seasons.

Among the many other topies with which the author deals, attention may be directed to the valuable account of holy and wishing wells. The book is a record of great value which, it may be hoped, will stimulate others to add to the material before it is too late.

\section{Our Bookshelf.}

Organic Syntheses: an Annual Publication of Satisfactory Methods for the Preparation of Organic Chemicals. Editorial Board: Hans T. Clarke, Editor-in-Chief; Roger Adams, James B. Conant; Henry Gilman, C. S. Marvel, C. R. Noller, Frank C. Whitmore, C. F. H. Allen. Vol. 10. Pp. vii +119 . (New York: John Wiley and Sons, Inc. ; London: Chapman and Hall, Ltd., 1930.) 8s. $6 d$. net.

Among the more familiar of the thirty-one preparations contained in this volume are benzenesulphonic chloride, benzophenoneoxime, methyl oxalate, and anhydrous oxalic acid. Useful practical details will be found under all these headings: thus, benzophenoneoxime is gradually converted into a mixture of benzophenone and nitric acid when kept under ordinary conditions, and a method of inhibiting this decomposition is given. The less common preparations include durene, duroquinone, and pyromellitic acid. The last-named compound is made by oxidising finely powdered pine or spruce charcoal with sulphuric acid in presence of a little mercury, and it is rêmarkable that ordinary willow charcoal failed to yield this benzene derivative when treated in a similar way. A useful apparatus for the application of superheated alcohols in the formation of various high-boiling ethyl and methyl esters is described under the heading of ethyl fumarate.

Of biochemical interest are the preparations of casein (from milk), $l$-tryptophane and $l$-tyrosine (from casein), taurine (from ethylene dibromide through sodium 2-bromoethanesulphonate), erucic acid (from rape seed oil), and lauryl alcohol (from cocoanut oil). There is also a noteworthy series of preparations departing from acetone and proceeding through bromoacetone and acetol to $l$ propylene glycol; the latter process affords an example of the biological method of asymmetric reduction by means of yeast reductase. An appendix contains later references to preparations in preceding volumes, but the index covers the current volume only. A revised collection of the contents of the first nine volumes is to be issued in due course. 